\title{
Key Drivers of an Effective Facilities Management Practice for Malaysia State Mosque
}

\author{
Maimunah Sapri ${ }^{1}$, Zafirah Ab Muin ${ }^{2, a}$ and Ibrahim Sipan ${ }^{3}$ \\ ${ }^{1,3}$ Centre for Real Estate Studies (CRES), Universiti Teknologi Malaysia (UTM), 81310 Skudai, Johor, Malaysia \\ ${ }^{2}$ Faculty of Geoinformation and Real Estate, Universiti Teknologi Malaysia (UTM), 81310 Skudai, Johor, Malaysia
}

\begin{abstract}
The paper discuss on the importance of facilities management (FM) in supporting mosque function and propose the key drivers for an effective FM practice for mosque. Qualitative research design was adopted in this study. Data were collected using focus group consists of seven (7) participants who have been selected among mosque management committee, FM practitioner and academician. Transcript of focus group discussion was analysed using content analysis. Coding system was applied in order to describe the interpretation of data. The results show that there is an agreement among participants on the importance of FM in supporting mosque function. Although practice of FM in mosque is not widely recognised, but its potential in uplifting and prospering mosque function could not be denied. Therefore, an effective of FM practice in mosque is seen vital. This paper discovered that team working is the most significant drivers to an effective FM practice for mosque. Other key drivers are organisational structure design; appoint knowledgeable and skilled facilities manager; sharing FM knowledge and its benefits; and strong change management. The discovered FM drivers are important for all stakeholders that directly or indirectly involve in mosque management.
\end{abstract}

\section{Introduction}

Facilities Management (FM) is becoming an increasingly important factor in the built environment. FM is often foreseen as an enabler to enhance organisational resources in a competitive and efficient way [1]. FM is a key function in managing facility resources, support services and working environment to support the core business of the organisation in both the long- and short-term [2]. An effective FM is a contributing factor of a total organisation success in which it contributes to the delivery of both strategic and operational goals. Therefore, the practice of FM in all organisation sectors is now progressively recognised.

Based on review of literature, the research on FM practice is widely discussed in various case studies such as in higher education institutions, health care services, commercial buildings and office buildings. However, it is discovered that the study which focusing on religious buildings such as mosque is still infancy. This is not surprising, as information on the importance of FM in supporting non-profit organisation to achieve its core business objectives is still lacking. Therefore, the objective of this paper is to discuss the importance of FM in supporting mosque function and propose the key drivers for an effective FM practice for mosque. Results of the findings will benefit to the stakeholders that directly or indirectly involve in mosque management. It is anticipate that the discovered drivers will act as enabler in order to play an important role in achieving prosperity as a mosque objective.

\footnotetext{
a Corresponding author: zafirah.hjabmuin@gmail.com
}

\section{Key Drivers of Effective FM Practice}

FM is a field that has a great impact in supporting the achievement of organisation goals effectively and efficiently. For that reason, FM profession has experienced a dramatic growth especially in the UK as one of the Western countries [3]. In contrast, FM is still infancy in terms of its practicing in the Asian countries, particularly in the South-East-Asia region [4], [5].

Research from [4] found that lack of understanding of the FM definition and roles has contributed to be part of the reason why FM is not being practiced proactively. [6] in [5] pointed out that FM challenges include lack of recognition, education and training needs, professional status, career pathways, information standard, performance benchmarking, cost value versus value in service procurement and corporate and community contribution of FM. These challenges will remain a barrier in the development of effective $\mathrm{FM}$, if the key drivers have not been explored [4].

Yet, the research of [7] found that even in the same business, FM practice of each organisation could be different which influenced by culture, business objective and nature of that organisation [2]. Therefore, it is essential to understand the factors affected FM practice in the establishment of appropriate FM arrangement [2]. In the context of this paper, those factors that has been suggested are referring to the key drivers, in which the key drivers that has referred are applies only in the scope of mosque. Besides, [8] claimed that 
identifying the key issues and drivers of effective FM practice will lead to the improvement and development of sustainable practice within the FM industry. For that reason, the key drivers of effective FM are discussed generally as below.

\subsection{Organisational Structure}

An organisation without a defined structure is likely to fail. Thus, an organisation's goals, mission and vision should be clearly defined. It is important that the structure of the organisation does not limit possibilities for future growth. According to [2], characteristic of an organisation has the major influence on the needs on facilities and support services of each organisation. [9] in [2] stated that the characteristics of an organisation should be addresses from time to time because organisational objectives and characteristics can be shifted or changed by business cycle and external environment. [8] claimed that strategic behaviour and performance of the organisation influenced by multiple actors like stakeholders, senior managers, government, employees, clients and supply chain in which there is a need of coordination between them.

[10] emphasised that senior management's leadership style and commitment may be a key driver of sustainability in organisation. Senior management commitment contributes to support the performance and goals of the entire organisation. Research findings by [11] stated that senior management personnel should be at the forefront of championing improvement of the level of commitment to effective FM practice within organisation. Findings also indicate that FM only can appreciable impact in an organisation if FM principles are fully embedded in the strategic function of organisation. Therefore, this factor can be the key driver for effective FM as it has the ability to acclimatize the changing environment.

\subsection{Knowledge and Skills of Facilities Manager}

According to the International Facilities Management Association (IFMA), FM is a profession that encompasses multiple disciplines to ensure functionality of the built environment by integrating people, place, process and technology. In the meantime, the British Institute of Facilities Management considers FM as the encompassment of multidisciplinary activities within the built and the management of their impact on people and workplace. Based on the definition, it can conclude that the role of facilities manager cover wide range of task and their decisions is required to be made at various management levels; strategic level, tactical level and operational level.

Knowledge, skills and abilities of facilities manager required performing those tasks [12]. It is important to ensure their effectiveness and performance. Since facilities managers are at the forefront of implement their organisation's vision and commitment, thus they had to develop their competencies to face the demands, challenges and opportunities for effective FM development and practice [8]. Therefore, establishment of FM profession in an organisation that have knowledge and quality skill is crucial importance to drive of effective FM practice [5], [13].

\subsection{Sharing of FM Knowledge}

Knowledge is now being seen as the most important strategic resource in organisations. Thus, there is an increase in organisations' effort to purposely manage knowledge in a systematic manner [14], as it is considered critical to organisational success. Knowledge can be divided into two, tacit and explicit [15], [16] in [14]. Review by [14] explains that both are different as tacit knowledge represents knowledge based on the experience of individuals expressed in human actions in the form of evaluation, attitudes, points of view, commitments and motivation. Conversely, explicit knowledge is codifiable knowledge inherent in non-human storehouses including organisational manuals, documents and databases

FM knowledge is very important to carry the best of FM practices [13], [14], [17]. Therefore, to ensure that the FM moves actively, FM knowledge is crucial importance need to be developed within organisation. As part of knowledge management processes, effective knowledge sharing is become pivotal as it could foster innovation by encouraging the free flow of ideas [18].

\subsection{Team Working}

An ultimate aim of FM in delivering good service quality is customer satisfaction. As FM plays a pivotal role between demand and supply, thus the team must provide with a clear and unambiguous brief, ensuring that FM is part of the strategic planning process [19]. Effective FM is essentially a team effort [20]. Successful FM teams will be able to embrace the language of the core organisation they serve, clarify and serve their strategic contribution in terms of business relevant outcome [21] in [4].

\subsection{Change Management}

Change is a movement from the present state of the organisation to a desired future state. Due to [5], the changes may boost the implementation of the FM. Management skills of a high order are necessary to achieve this major change, together with learning and consolidating the skills base [19]. Thus, appropriate training must be provided for introduction and development of FM skills. Facilities manager must become catalysts of change in the ways in which the services are provided.

\section{The Need of Effective FM Practice to Increase Mosque Function}

In Islamic literature, mosque is the house of Allah and known as a non-profit organisation. Importance of this institution could be seen through its roles and functions as a place of worship, a spiritual centre for the Muslim community, and a focal point for Islamic activities. In the Islamic culture, 'Masjid', or Mosque is considered as the most important sacred structure [22]. Therefore, the Mosque is deserves to be shown the respect and given the honor, and should be functional strictly accordance with the Qur'an and the Sunnah of the Prophet (peace be upon him).

Due to largest Muslim population, Malaysia has numerous mosque dispersed all over urban and rural areas [22]. However, it seen that the function of mosque is become lacking. Due to the time changes, functions of the mosque become narrow and only well-known as a place to perform worship among today generation. Moreover, the Malaysian 
Government had spent almost billion ringgit to build a mosque. Most of the mosques are good at architecture design, but getting worse in number of people come to mosque which is refer to the congregational. In the context of this paper, the congregation can be classified into two group; internal customer (visitor) and external customer (employees).

\subsection{Importance of Customer Satisfaction to Gain Involvement}

Lack of awareness among community on the importance of mosque is the factor contributed to the issue of prospering mosque [23]. Moreover, there are several of researcher stated that potential for mosque to be prosper has been affected by the lack of competencies in leadership [24], less vigorous activities and programs [23], lack of attention of conducive physical environment [25], [26], [27], [28], lack of userfriendly, youth-friendly, family and community-friendly approach [23], [29], [30] and poor financial management to implement mosque activities [31], [32].

Mosque is community-based organisation [24]. Thus, involvement of the congregation to prospering the mosque is critical factor that contribute to mosque to be functional as a whole. In FM concept, the congregation is classified as a customer where it has a significant impact on the performance of a business [33]. As a social-service organisation, mosque should consider to meet the expectations and requirements of customer in delivering service. A good service quality will produce customer satisfaction as the output [34], in which there is a strong relationship between customer satisfaction and customer loyalty [33]. According to [35], if the organisation fails to deliver the right products and services that satisfying customer needs, most probably the business will wither and die. Therefore, it is important for mosque to consider the expectation and requirement of the congregation to sustain its business continuity.

\subsection{The Requirement to Provide Conducive Environment}

Prosperity of mosque has a special relationship with Allah's mercy. Refers to Islamic Hadith from Ali bin Abi Thalib r.a. stated that:

The Prophet Muhammad (peace be upon him) reported:

"It is almost a time when there is no more Islam except its name, and there is not stay out of the Quran except its writing. Their mosque stately, but it is empty of guidance. Their Ulama are the worst of creatures that exists under the vault (shade) sky. From them defamation belongs, and to them the defamation will return".

(Al-Baihaqi, Hadith no: 1766)

Based on the Hadith, it reveals the requirements to ensure mosque should be function as the preferences place of people in seeking the guidance. For mosque to be functional as it is, thus environment of mosque should pleasant and welcoming the congregation. Design, decor and aesthetics of the religious places could bring people closer to religious ideals, spirituality, community, and peace and consequently influence their attachment [36]. They also mentioned that religion has a profound influence on people's relations with the sacred places and on their attachment to those settings.
Thus, not only the physical of mosque should be good at architecture and maintenance but also should be capable as a place for community development that meets their needs.

Similar with higher education institution purposes, mosque also responsible in producing leader of calibre and integrity. Many suggestions by Islamic scholar stated that young people should be encouraged in prospering the mosque [23], [28], [29], [37]. They strengthen that this group has high potential to be educated and nurtured with values from the beginning. Various programmes and activities should be implemented effectively in order to planting the sense of belonging towards mosque institution. Thus, mosque should be equipped with adequate and well maintained facilities in order to support the implementation of those planned activities run smoothly.

However, there are many cases reported regarding mosque environment issues that should be given serious attention. For instance, there is a case on the lack of maintenance within mosque building where the roof of mosque building unexpectedly has been collapsed. As sacred place where could be preferences place to gain serenity, but unfortunately mosque has confronting with this problem. This situation has raised the issue of safety in mosque construction.

\subsection{Tackle Mosque Management Issue}

Even though mosques are no longer used as state administration centres, their role in shaping society still continues [38]. The key challenge of managing mosques today is to ensure efficient and proper management practices [38]. Therefore, in order for mosques to uplift their multifunctionality in today's modernization era, and to be sustained into the future, the issue of professional management is among those topics that need to be discussed. Mosques should be operated through a more professional management system, in order to meet current needs and demands [23], [38], [39].

The right management practices will contribute to improving a mosque's performance [39]. The research has identified that the management of mosques facilities is becoming crucial, as it contributes to mosque success in delivering mosque core functions to the community. Therefore, mosques require the effective and efficient management of their facilities. In this regard, facilities management (FM) is seen to be the approach that mosques could consider. FM is a subset of general management [40]. As a subset of general management, it will help to improve processes through which organisations can be managed, in order to support their effectiveness, and to make a positive contribution to organisation success.

The level of mosque functionality is highly depends on participation of community. Therefore, requirement in providing good facilities is seen vital in order to support mosque in achieving its objectives [25], [26], [28]. In the context of this research, good facilities are referring to level of functionality and durability facilities in facilitate the customer to perform their activities. Hence, in providing good facilities, then it requires an effective and efficient of FM. Figure 3.1 is presenting the relationship between FM and mosque in order to have a clear overview on requirement of FM in supporting mosque function. 


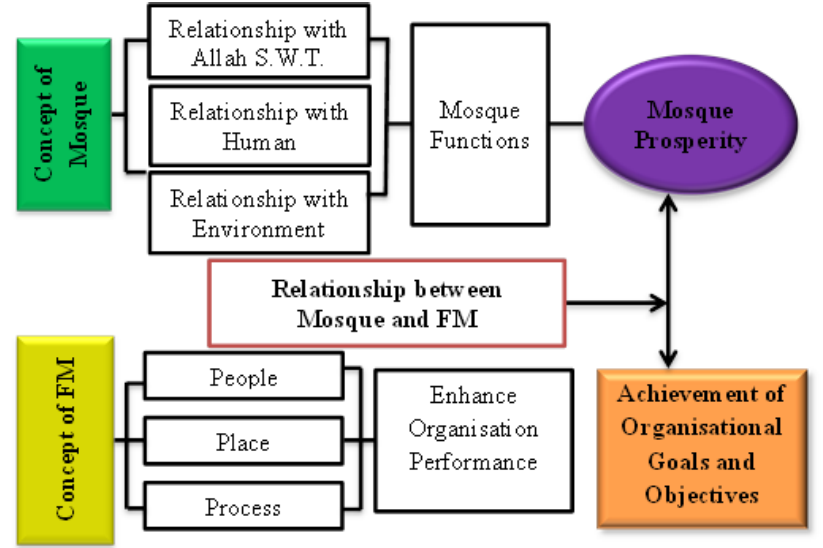

Figure 3.1: Framework of Relationship between FM and Mosque Function

Source: Sapri and Ab Muin (2014)

\section{Research Methodologies}

The research was designed to solicit the views and in order to identify key drivers for an effective facilities management practice in mosque institution. Since there is no FM research has been conducted before in the context of mosque institution, therefore qualitative research method is used in order to provide an insight and understanding on how FM should be practice and what are drivers confronting an effective FM practice in mosque. Qualitative research is best suited to address a research problem that do not know and need to explore [42].

Focus group approach of data collection was adopted. Seven (7) respondents which representing the mosque management, mosque facilities manager, practitioner of FM and academicians participated in the focus group discussion. Focus group was selected in terms of its advantage in providing insights into how people think and provide a deeper understanding of the phenomena being studied [43]. Moreover, group interaction and non-verbal communication are primary benefits of focus group. The interaction among members of the target population during focus groups meetings may inspire participants to make connections to various concepts through the discussion which may not occur during individual interviews [43]. Moreover, focus group refer to focused and interactive session with a small group which enough for everyone to have a chance to talk and large enough to provide diversity of opinions. Therefore, focus group adopted in this study purposely to find out drivers for effective FM practice in mosque institutions from the target population.

Focus group research involves organised discussion with a selected group of individuals to gain information about their views and experiences of a topic [42]. Moreover, focus group interviewing is particularly suited for obtaining several perspectives about the same topic. Therefore, the focus group was considered the most appropriate method in examine the drivers for effective mosque FM practice as it assemble parties that directly involved in management of mosque and facilities.

The question involved open-ended questions because the intent of the focus group is to promote discussion [43]. In this study, participants have been asked open-ended question based on their experience and opinions to achieve the objective of this study. The role of the moderator is very significant for conducting focus group successfully [42]. Thus, two moderators with good levels of group leadership and interpersonal skill have been appointed during the discussion. List of participants are listed in Table 4.1 below.

Table 4.1: Code, Position and Organisation

\begin{tabular}{|cll|}
\hline Code & \multicolumn{1}{c|}{ Position } & \multicolumn{1}{c|}{ Organisation } \\
A & Academician (PhD.) & $\begin{array}{l}\text { Universiti Teknologi } \\
\text { Malaysia }\end{array}$ \\
\hline B & $\begin{array}{l}\text { Academician (Assoc. } \\
\text { Prof) }\end{array}$ & $\begin{array}{l}\text { Universiti Teknologi } \\
\text { Malaysia }\end{array}$ \\
\hline C & $\begin{array}{l}\text { Person in Managing } \\
\text { Mosque }\end{array}$ & Salman Mosque, Indonesia \\
\hline D & $\begin{array}{l}\text { Person in Managing } \\
\text { Mosque }\end{array}$ & $\begin{array}{l}\text { As-Syakirin Mosque, Kuala } \\
\text { Lumpur City Centre }\end{array}$ \\
\hline E & $\begin{array}{l}\text { Person in Managing } \\
\text { Mosque }\end{array}$ & $\begin{array}{l}\text { Masjid As-Salam, Puchong, } \\
\text { Selangor, Malaysia }\end{array}$ \\
\hline F & FM Practitioner & $\begin{array}{l}\text { Facility Management } \\
\text { Tradewinds Corp. Bhd. }\end{array}$ \\
\hline G & Valuer & $\begin{array}{l}\text { National Institute of } \\
\text { Valuation } \\
\text { (INSPEN),Malaysia }\end{array}$ \\
\hline
\end{tabular}

To identify the individual view from the group view, participants were asked to share their experience and opinions on how FM should be practice effectively in mosque. The data was analysed using content analysis approach. Qualitative content analysis highlights an integrated view of speech or texts and their specific contexts. It goes beyond basically counting words or extracting objective content from texts to examine meanings, themes and patterns that may be visible or latent in a particular text [44]. In this study, participants were selected according to their respective areas of expertise. The key drivers of effective FM for mosque were derived from the speech in which the data are read word by word to derive codes. The exact word was highlights from the text that appear to capture key thoughts or concepts.

After gather all the data, the key feature of all content analysis is that the many words of the text are classified into much smaller content categories.

These content categories should be guided by the aim and research question of the study in choosing the contents analyse [44]. This process includes open coding and abstraction. The words were counted and based on the highest frequency abstraction, thus it is ranking within the categories in order to have better analyse and describing on the phenomenon. Once this is done, the information has been analysed and a conclusion has been drawn. [43] postulate that the success of the research depends on how the content was analysed and the coding process behind the data.

For the focus group, the data has been classified into five (5) categories as presented in Table 4.2. The coding categories were derived from the text data. Each category was then interpreted within the underlying context in achieving the objective of this study. 
Table 4.2: Coding Categories

\begin{tabular}{|c|c|}
\hline No. & $\begin{array}{c}\text { Key Drivers of An Effective FM Practice for } \\
\text { Mosque }\end{array}$ \\
\hline 1. & Design of Organisational Structure \\
\hline 2. & $\begin{array}{l}\text { Appointing a Facilities Manager by Knowledge and } \\
\text { Skill }\end{array}$ \\
\hline 3. & Sharing of FM Knowledge and Its Benefit \\
\hline 4. & Spirit of Team Work \\
\hline 5. & Strong Change Management \\
\hline
\end{tabular}

\section{Results}

Data collated from interview transcript are analysed and the findings are discussed below. All the statements made by the respondents with regard to the research question are based on their view on the importance of FM in supporting mosque function and what are the drivers in order to effective implement of FM in mosque institution. In the section below, some of the aspects for effective FM practice identified earlier are discussed.

\subsection{Importance of FM in Supporting Mosque Function}

FM practice has been identified as essential ingredient for achieving organisational objectives. A more good perspective on the importance of FM in supporting organisational in achieving its goals particularly in the context of mosque institution are captured in the statement made by respondents:

\section{Respondent A:}

"There are four main objectives of mosque; facilitate as a place of Islam development, a place to perform worship, a place of education and a place for community development. Mosque is not a structure, mosque is not a building. But mosque is the human. Human are responsible to develop the mosque. If the human hearts close to mosque, thus the mosque will prosper. Therefore, FM in mosque is crucial to support all these functions since the element of people is the main focus in FM principle. Perhaps, this is our ultimate aim to prosper the mosque".

\section{Respondent B:}

"Mosque is an institution. If referred to the definition of institution, it is not only referring to human, it is not only referring to physical. I would like to use the analogy which building is our 'deen'. For instance, mosque building which is its main function is to obtain blessing. It not only consists of human, but mosque becomes a place for recognition on the economic, ethics and etc. Thus, when we referred to the analogy of physical, we could not avoid that there is a combination between mosque function physically and the person who use the mosque. Based on knowledge sharing among the participants, FM is actually has been practice in mosque where FM can be classified as management tool or method. FM encompasses the elements of people, process and place. In order to synchronize those three elements with mosque functions, thus technology is required to perform work more efficiently and effectively. Moreover, FM as an approach has the potential to support and sustain mosque functionality in terms of business continuity, environment and finance".

\section{Respondent D:}

"FM is important in managing mosque since FM is an approach that covers wide range of field. Therefore, competency of facilities manager in managing mosque is the needed".

\section{Respondent E:}

"Logically, mosque should be provided with good facilities such as cleaning, carpet, air-conditioning, etc. in order to encourage people to prosper the mosque".

\section{Respondent F:}

"FM is support services where its function is helping the organisation implement its core business. When we talk about FM, we as the practitioner see FM as the technical support. We operate and maintain the facilities for the building owner to make sure those facilities are operating in optimum condition and lifespan. Thus, it is required in managing mosque".

Based on respondents' view, it can be concluded that FM is importance in supporting mosque function. There is an agreement in which the facilities management function can act as a facilitator for mosque institution to achieve its objectives. Even though, it is not confirms that an effective FM in mosque will definitely contribute to the mosque to be prosper, but its importance as one of the management tools should not be underestimated.

\subsection{Key Drivers for an Effective FM Practice in Mosque}

Data collected from the focus group interview are analysed through content analysis technique. Based on the findings, most of the participants agreed that design of organisational structure (respondent A, B and C), appointing knowledge and skilled of facility manager (respondent D, F and G), sharing of FM knowledge and its benefit (respondent $\mathrm{C}$ and $\mathrm{D}$ ) and spirit of team work (respondent A, B, D and E) are the key drivers that contribute to an effective FM practice for mosque. However, only one participant (respondent B) stressed that change management should become one of the key drivers of an effective FM for mosque. The summary of the key drivers related to an effective FM practice for mosque are presented below.

\subsubsection{Design of Organisational Structure}

From the discussion, respondent $\mathrm{A}, \mathrm{B}$ and $\mathrm{D}$ have mentioned that organisational structure factor contribute to drive effective FM practice for mosque. The respondent strengthen that organisational structure should be designed from top to down and FM must be involved not only at operational level, but also at strategic and tactical level. Thus, FM can widely 
executed in mosque management. Moreover, the respondent also advise the Department of Religion as the stakeholder to do a revision on their current organisational structure to ensure there is person who have skill, experience and certificate in FM.

\section{Respondent A:}

"Having a strong organisational structure is essential for organisation growth. Planning the good organisational structure helps to ensure enough human resources within organisation to accomplish the goals set forth in the organisation action plan".

\section{Respondent B:}

"There is requirement for mosque FM practice to be sustained. Thus, when we design the organisation structure, we should design from top to down. It means that we need to tackle every level either strategic level, tactical level or operational level".

\section{Respondent D:}

"My suggestion to Department of Religion is to revise their organisational structure and look into the people that need the skill, experience and certified in FM"'.

\subsubsection{Appointing a facilities manager by knowledge and skill}

Respondent D, F and G stated that it is important for mosque to appoint the right person to manage facilities. The right person is referring to the person who has professional FM background that was accredited by the university. Due to wide scope of FM, therefore knowledge and skill of facilities manager should be in place in mosque.

\section{Respondent D:}

"Appointment of facilities manager in mosque should be considered in which the person who will be appointed should have the background in facilities management field".

\section{Respondent $F$ :}

"The world increasingly sophisticated as well as the technology is growing. Mosque is supplied with PA system, projector, acoustic evaluation, etc. Thus, all these matters require technical team that have specific skill. This technical team will cover mechanical system, electrical system, civil and structure, housekeeping, landscape, security and indoor environment which consider user's comfort and safety at mosque. Hence, it can be seen that effective FM that supported by skilled team is essential in prospering mosque".

\section{Respondent $G$ :}

"We need to recognise who is the right person in responsible to manage the mosque facilities. For instance,
Universiti Teknologi Malaysia (UTM) has produce graduates in FM. Thus, these graduates have high potential to spearhead the management of facilities".

\subsubsection{Sharing of FM Knowledge and Its Benefits}

Respondent $\mathrm{C}$ and $\mathrm{D}$ mentioned that FM knowledge and its benefits should be exposed and shared widely at the mosque. This effort should be spread among mosque management and the congregation to increase awareness and generate ideas among them.

\section{Respondent $C$ :}

"Benefit is the main factor for FM to be practice effectively in mosque. Facilities provided in mosque that meet the user's requirement will contribute to encourage people to prosper the mosque. Sharing on benefit of the facilities to the congregational contribute to willingness in term of donation. So, provision for facilities development will become more interactive since there is participation from the congregational".

\section{Respondent D:}

"FM knowledge should be exposed to mosque management. Besides, the FM knowledge exposure should be consists of on how to optimise space, how to generate income, how to make long-term and short-term strategic planning in more systematic, etc."

\subsubsection{Spirit of Teamwork}

Respondent A, B, D and E share the same opinions that spirit of team work is crucial to an effective FM practice for mosque. Moreover, level of professionalism and commitment among mosque management from top level to bottom contribute to successful of any proposal in future.

\section{Respondent A:}

"Level of professionalism and commitment among mosque management either at the top level or bottom level are critical in managing mosque because its profit does not depend on money but to achieve the reward from Allah S.W.T. which is far better than anything else. When this factor was successful, thus any proposals or papers be forwarded will be realized with distinction".

\section{Respondent B:}

"Human is the most crucial factor where this human factor is not only referring to person in managing mosque, but the user of the mosque".

\section{Respondent D:}

"Teamwork is important factor to be considered. Less cooperation among mosque management will contribute to 
IBCC 2016

lack of sharing the resource. Lack of knowledge sharing for example will affect mosque capabilities for higher mosque performance".

\section{Respondent E:}

"Any works without teamwork is worthless. Hence, passion among team member that involve in mosque from top management to the bottom is highly required".

\subsubsection{Strong Change Management}

Opinion from respondent $B$ stated that strong change management is required to effective FM practice for mosque. Change management should be positively accepted among the mosque management, from top level to bottom level.

\section{Respondent B:}

"In my opinion, strong change management is essential to sustain mosque function. Same goes to effective FM practice; it is highly depends on the acceptance of mosque management. Thus, involvement of FM at strategic level is needed in order to expose the importance of FM in achieving mosque objective. Once again, for me change management is crucial factor in which it requires an action from various parties to participate".

\section{Discussion}

Based on the focus group discussion with the respondents, they agreed that FM is one of the approaches to assist mosque in achieving core objectives and supporting its function. According to one of the respondents, FM is classified as management tool or method. Thus, FM has the potential to be adopted in management of mosque as it can helps to sustaining mosque functionality in terms of business continuity, environment and finance. Since the focus of FM is customer oriented, therefore good management of mosque facilities is crucial to gain congregational contribution in prospering the mosque.

Through the discussion with focus group, the key drivers of an effective FM practice for mosque are also have been identified. From the findings, it can be conclude that an effective FM practice in mosque requires a transformation or a change among mosque management itself. in order to the transformation is successful implemented, mosque management should be properly design their organisational structure, appointing knowledge and skill facility manager, sharing of FM knowledge, increase spirit of team working and have strong change management.

For instance, organisation structure design has been classified as one of the key drivers for effective FM practice. It shows that designing an effective organisation structure is important as it helps top management to identify talent that needs to be added to the organisation. In addition, planning the structure ensures there are enough human resources within the organisation to accomplish the goals, mission and vision.

Furthermore, it is important that responsibilities are clearly defined. This is support by the literature from [8] stated that strategic behaviour and performance of the organisation influenced by multiple actors like stakeholders, senior managers, government, employees, clients and supply chain. Therefore, designing mosque management structure is become vital for implementation of effective FM practice.

As mentioned by [11], senior management personnel should be at the forefront of championing improvement of the level of commitment to effective FM practice within organisation. Thus, revising mosque organisational structure is required in order to addressing professional human resource management and gaining top management commitment issues in managing mosque facilities.

Moreover, there are some respondents stated that coordination of FM approach should be initiated not only at the operational level, but also should be executed at the strategic level. Through the implementation of the FM practice at the strategic level, it will assist the effectiveness and performance of FM practice in mosque. Therefore, commitment and participation from the stakeholders, senior management, employees and the congregational is crucial. This statement is supported by [11] in which his research findings indicate that FM only can be appreciable impact in an organisation if FM principles are fully embedded in the strategic function of organisation.

Furthermore, the findings of this study are consistent with the argument that knowledge and skill of facility manager is important in order to ensure the effectiveness and performance of FM practice [5] [12] [13]. Most of respondent stated that it is necessary to appoint facility manager with FM background to enable and facilitate the implementation of FM practice in the context of mosque. This key driver is become important since there is no establish FM unit or position for facility manager in mosque.

Review from literature mentioned that the increasing awareness by promoting the need of FM as part of the business organisation contribute on the development of FM [5]. Therefore, findings of this study reveals that sharing of FM knowledge and its benefit is become one of the key drivers that need to be considered. It is important especially stakeholders of the mosque understand on how FM can and should contribute in supporting mosque functions.

The journey of a thousand miles begins with one step. In order to ensure FM effectively implemented in mosque, thus, it require the involvement from each level; strategic, tactical or operational [20]. Based on the findings, most of the respondents stressed the importance of team working that contributes to the effective FM practice. Moreover, Islamic literature claimed that mosque is a unique and extraordinary building compare to other building and social service industries [23]. Its profit is not monetary base, but more on the desire in expect reward from Allah S.W.T. [41]. Thus, most of respondent agreed that teamwork becomes the critical and important drivers that contribute to an effective FM practice in mosque. In addition, there is a respondent stressed that it is an essential to consider change management in the transformation of mosque. As mentioned by [5], the changes may boost the implementation of the FM and it is a movement from the present state of the organisation to a desired future state.

\section{Conclusions}

This paper presented the overview of the key drivers of an effective FM practice in mosque. It can be said that adapting FM approach in mosque is still infancy. It is discover that there is specialisation should be made to encourage FM practice in mosque. In order to reinforce the mosque as a robust and unified institution as the place for community 
centre, a comprehensive plan should be formulated with emphasized the practice of effective FM with considered the drivers that being identified in this study. This paper concluded that the FM practice should be aligned with the mosque's strategic goals. It is very importance for effective FM practice to demonstrate that convenient FM processes is capable in giving positive impact in prospering the mosque. Thus, FM approach will supporting to the best practice in managing mosque through providing good facilities in future and guarantee for long-term benefits.

\section{Acknowledgement}

The authors would like to acknowledge and thank to the funder of this research project, Real Estate Research and Development Grant Scheme (NAPREC) between The Government of Malaysia and Universiti Teknologi Malaysia under Vot. No: R.J130000.7309.4B134 for funding this research work.

\section{References}

1. Sapri, M., Kaka, A. and Finch, E. (2009), "Factors that Influence Student's Level of Satisfaction with Regards to Higher Education Facilities Services", Malaysian Journal of Real Estate, Vol. 4, No. 1.

2. Chotipanich. S. (2004). "Positioning Facility Management", Facilities, Vol. 22 Iss 13/14 pp. 364-372.

3. Myeda, N. E. and Pitt, M. (2014), "Facilities Management in Malaysia: Understanding the Development and Practice", Facilities. Vol. 32 Nos 9/10, pp. 490-508.

4. Kamaruzzaman, S.N. and Ahmad Zawawi, E.M. (2010),"Development of Facilities Management in Malaysia", Journal of Facilities Management, Vol. 8 Issue 1 pp. $75-81$.

5. Syed Mustapa, S.A.H., Adnan, H. and Jusoff, K. (2008), "Facilities Management Challenges and Opportunity in the Malaysian Property Sector", Journal of Sustainable Development, Vol. 1 No. 2, pp. 78-85.

6. Ballesty, S. (2007), "Best Practices and Success Stories in Asset and Facility Management", Proceeding of the National Asset and Facilities Management (NAFAM) Convention, Kuala Lumpur, Malaysia, 13 August.

7. Schindler, K. (1998), "The Role of FM within the Retail Sector", Msc. Dissertation in Facility Management, University College, London.

8. Elmualim, A., Valle, R. and Kwawu, W. (2012), "Discerning Policy and Drivers for Sustainable Facilities Management Practice", International Journal of Sustainable Built Environment, Vol. 1, pp. 16-25.

9. Lee, W. (2002), "The role of support services and FM in the introduction of change management", in Reuvid, J. and Hinks, J. (Eds), Managing Business Support Services, 2nd ed.

10. Elmualim, A., Shockley, D., Ludlow, G. and Shah, S. (2010), "Barriers and Commitment of Facilities Management Profession to the Sustainability Agenda", Built and Environment, 45 (2010) 58-64.

11. Dubem, I. I., Stephen, O.O., Michael, G.O. and Timothy, A. (2013), "Assessing the Level of Commitment and Barriers to Sustainable Facilities Management Practice: A Case of Nigeria", International Journal of Sustainable Built Environment.
12. Amaratunga, D. (2001), "Theory Building in Facilities Management Performance Measurement: Application of Some Core Performance Measurement and Management Principles", Doctor of Philosophy Dissertation, the University of Salford, United Kingdom.

13. A.M. Firdauz M. Sapri I.S. Mohammad. (2015), "Facility Management Knowledge Development in Malaysia”, Facilities, Vol. 33 Issues 1/2 pp. $99-118$.

14. Pathirage, C., Haigh, R., Amaratunga, D. and Baldry, D. (2008), "Knowledge Management Practices in Facilities Organisations: A Case Study", Journal of Facilities Management, Vol. 6, Issue 1, pp. 5-22.

15. Polanyi, M. (1958), "Personal Knowledge towards a Post-Critical Philosophy", Routledge and Kegan Paul Ltd, London.

16. Nonaka, I. and Takeuchi, H. (1995), "The Knowledge Creatinf Company: How Japanese Companies Create the Dynamics of Innovation", Oxford University Press, New York.

17. Nutt, B. (2002), "Event 1.7: Positioning FM", Lecture Note Module 1: Introduction to Facility Management, University College London, London.

18. Mohammed Fathi, N., Cyril, U. Gerald, E. and Goh, G. G. (2011),"Key Determinants of Knowledge Sharing in an Electronics Manufacturing Firm in Malaysia", Library Review, Vol. 60 Issues 1 pp. $53-67$

19. Alexander, K. (1992),"Facilities Management Practice", Facilities, Vol. 10 Issue 5 pp. $11-18$.

20. Hamilton, B. (2003), "Overview and Trend in Facilities Management", paper presented at Facilities Management Seminar 2003, University of Technology Mara (UITM), Selangor.

21. Hallam, S. (2007), "FM Research - the Leading Edge", Facilities, Vol. 18, No. 7.

22. Najafi, M. and Mohd Shariff, M.K. (2014), "Public Attachment to Religious Places: A Study of Place Attachment to Mosques in Malaysia", International Journal of Social, Behaviour, Educational, Economic and Management Engineering, Vol. 8 No. 1.

23. Mohamad Rasdi, M. T. (1998), "The Mosque as a Community Development Centre: Programme and Architectural Design Guidelines for Contemporary Muslim Societies". University Teknologi Malaysia.

24. Mahazan, A.M. (2013), “A Model of Imam's Leadership and Mosque Performance in Malaysia", GJAT, Vol. 3 Issue 2 | 55, ISSN: 2232-0474 | E-ISSN: 2232-0482. www.gjat.my.

25. Safar, A.J. (2008), "Institusi Masjid Dalam Memperkasakan Pembangunan Modal Insan", Book Chapter of Pengurusan Berkualiti Memacu Kecemerlangan Pengurusan Masjid. Universiti Teknologi Malaysia.

26. Muda, Z. and Omar, N. (2008), "Limitasi dan Absolutasi Aktiviti Masjid Menurut Islam”, Book Chapter of Pengimarahan Masjid Dalam Agenda Ummah. Universiti Teknologi Malaysia.

27. Mohamed, R. (2008), "Pemerkasaan Masjid Melalui Pengurusan Profesional", Book Chapter of Pengurusan Berkualiti Memacu Kecemerlangan Pengurusan Masjid. Universiti Teknologi Malaysia.

28. Khalit, N. A. (2011), "Revitalizing Roles and Functions of Mosques in Kuala Lumpur, Master Thesis, Universiti Teknologi Mara (UiTM). 
29. Ali Khan, M.N.A, Salleh, M.Z. and Salleh, N. (2008), "Pengurusan Masjid: Satu Tinjauan Ke Atas Masjid Cemerlang", Book Chapter of Pengurusan Berkualiti Memacu Kecemerlangan Pengurusan Masjid. Universiti Teknologi Malaysia.

30. Jamsari, E.A., Tumiran, S.N., Abu Bakar, K. and Arifin, Z. (2010), "Peranan dan Sumbangan Institusi Masjid dalam Pembangunan Masyarakat Melayu-Islam di Singapura: Satu Kajian di Masjid Assyafaah, Sembawang", Journal of Islamic and Arabic Education, 2(2), 2010 31-44.

31. Siraj, S.A, Mohamed Ibrahim, S.H. and Sulaiman, M. (2008), "Pengurusan Kewangan: Mempamerkan Akauntabiliti Masjid", Book Chapter of Pengurusan Berkualiti Memacu Kecemerlangan Pengurusan Masjid. Universiti Teknologi Malaysia.

32. Bahrom, H. (2008), "Menjana Sumber Kewangan Masjid Pemangkin Pembangunan Ekonomi Ummah", Book Chapter of Pengurusan Berkualiti Memacu Kecemerlangan Pengurusan Masjid. Universiti Teknologi Malaysia.

33. Sapri, M., Kaka, A., and Finch, E. (2009). "Factors That Influence Student's Level of Satisfaction With Regards To Higher Educational Facilities Services", Malaysian Journal of Real Estate 4(1).

34. Sapri, M., Kaka, M. and Alias, B. (2010), "Performance Management in Service Business: The Facilities Management Function", Online Publication.

35. Amaratunga, D., Baldry, D. and Haigh, R. (2004), "Customer Related Facilities Management Process and Its Measurement: Understanding the Needs of the Customer", Research Institute for the Built and Human Environment, The University of Salford, United Kingdom.

36. Mazumdar, S. and Mazumdar, S. (2009), "Religion, Immigration, and Home Making in Diaspora: Hindu Space in Southern California. Journal of Environmental Psychology, 29: p. 256-266.

37. Jamsari, E. A., Tumiran, S. N., Abu Bakar, K. and Arifin, Z. (2010), "Peranan dan Sumbangan Institusi Masjid dalam Pembangunan Masyarakat Melayu-Islam di Singapura: Satu Kajian di Masjid Assyafah, Sembawang, Journal of Islamic and Arabic Education, Vol. 2(2), pp. 31-44.

38. Mohamed Adil, M.A., Mohd Sanusi, Z., Jaafar, N.A., Khalid, M.M., Abd Aziz, A. (2013), "Financial Management Practices of Mosques in Malaysia", GJAT, Vol. 3 Issue 1/24, ISSN: 2232-0474, E-ISSN: 22320482, www.gjat.my.

39. Jaafar, A., Habidin, N.F., Mohd Hussin, M.Y., Zakaria, Z. and Abdul Hamid, A. (2013), "A Proposed Model for Strategic Management (SM) and Mosque Performance (MP) in Mosque Management", International Journal of Management, Information Technology and Engineering, Vol. 1, Issue 3, pp. 29-36.

40. Amaratunga, D. and Baldry, D. (2000), "Assessment of Facilities Management Performance in Higher Education Properties", Facilities, Vol. 18, Issues 7/8, pp. 293-301.

41. Sapri, M. and Ab Muin, Z. (2014), "Peranan Pengurusan Fasiliti Ke Arah Pengimarahan Masjid", International Conference of Mosque Facilities Management (ICMFM): Special Edition, Centre for Real Estate Studies, Universiti Teknologi Malaysia.
42. Cresswell, J.W. (2012), "Educational Research: Planning, Conducting and Evaluating Quantitative and Qualitative Research", Fourth Edition, Pearson Publication.

43. Williams, Nagle, B. and Nichelle (2013), "Methodology Brief: Introduction to Focus Group. Center for Assessment, Planning \& Accountability. http://www.uncfsp.org/projects/userfiles/File/FocusGrou pBrief.pdf

44. Wildemuth, Zhang, Y., and Barbara, M. (2013), "Qualitative Analysis of Content", http://7702f13.design4complexity.com/qualitative-research/contentanalysis.pdf 